\title{
WALTER ŻELAZNY
}

UNIWERSYTET W BIAŁYMSTOKU

WALTERZ@HOTMAIL.FR

\section{WIELOKULTUROWOŚĆ ZAMENHOFA AVANT LA LETTRE ZE SZCZEGÓLNYM UWZGLĘDNIENIEM ASPEKTU RELIGIJNEGO}

W niniejszym eseju piszę o wielokulturowej Rzeczypospolitej (formalnie) Obojga Narodów, w istocie wielokulturowym i wielowyznaniowym państwie, które samo sobie zgotowało zmierzch (trwał on prawie dwa wieki) kończący się rozbiorami, nie do końca potrafiąc zarządzać głównie wielowyznaniowym, ale również wielokulturowym tworem. Rodząca się poza etnosem polskim inteligencja dawnej Rzeczypospolitej głównie ukraińska, białoruska, litewska języka lietuviu oraz żydowska języków polskiego i jidysz) stawała przed nowymi wyborami narodowymi i wyznaniowymi. Następowała polaryzacja narodowa. Szczególną uwagę poświęcę zagadnieniu, w jaki sposób Ludwik Zamenhof, wierny judaizmowi, zmierzał się $\mathrm{w}$ tym okresie $\mathrm{z}$ kwestiami narodowymi.

\section{Okres rozbiorów}

Okres rozbiorów kończy byt Rzeczypospolitej Obojga Narodów i dzieje się to $\mathrm{w}$ okresie największego nasilenia myśli oświeceniowej w Polsce, dorównując niekiedy toutes proportions gardées politycznej myśli oświeceniowej Francji i Stanów Zjednoczonych. Osierocamy wraz z rozbiorami całe rzesze najróżniejszych postaci dla Rzeczypospolitej Obojga Narodów wybitnych, wcale niepolskich i wcale niekatolickich, bez których to dzieje Rzeczypospolitej byłyby bezbarwne, nijakie; wymienię tu przykładowo rody Ostrogskich, Chodkiewiczów, Firlejów, Whalów czy Ezofowiczów. W okresie rozbiorowym, ale i długo po nim, ich rodziny, czy członkowie ich rodzin, dokonują najróżniejszych wyborów narodowych i wyznaniowych, które najczęściej nazywamy konwersjami. Są to często konwersje prawosławnych rodów ruskich i litewskich na polskość i katolickość, ale, choć 
rzadziej, również odwrotnie. Starszy brat prezydenta Gabriela Narutowicza (1865-1922) Stanislovas Narutavičius (1862-1932) staje się członkiem litewskiej Tarby i zostaje jednym z pierwszych sygnatariuszy aktu niepodległości Litwy. Wybitny kompozytor muzyki współczesnej Grażyna Bacewicz (1909-1969) zostaje Polką, jej brat Vytautas Bacevičius (1905-1970) Litwinem. Bracia generała Stanisława Szeptyckiego (1867-1950), ministra wojny z okresu zamachu majowego Piłsudskiego z 1926 stają się zdeklarowanymi Ukraińcami (inna rzecz, że wracają do korzeni, pochodzą bowiem z Wiśniowieckich) - Andrzej 1865-1944 zostaje greckokatolickim metropolitą lwowskim, a Klemens (1869-1951) ihumenem klasztoru w Uniowie oraz archimandrytą Studytów.

Przez najróżniejsze osobiste manifestacje niektórzy intelektualiści wskazują na swe sympatie narodowe i polityczne. Na przykład Józef Mackiewicz (1902-1985), brat Stanisława Cata Mackiewicza (1896-1966), demonstracyjnie zawiera ślub w 1938 w cerkwi prawosławnej w Wilnie i deklaruje się prawosławnym w proteście burzenia cerkwi na Chełmszczyźnie, czego dziś nie zauważają jego prawicowi apologeci. Również Czesław Miłosz (1911-2004) lubił z przekory dopiekać do żywca endekom, mówiąc, że jest Litwinem, a jego wuj Oscar (1877-1939), poeta, był niewątpliwie zaprzysięgłym Litwinem. By zakończyć z przykładami przypomnę, że Adalbert von Winkler (1838-1918) zostaje Wojciechem Kętrzyńskim, któremu Antonina Kłoskowska poświęciła odrębne, klasyczne już dziś studium Konwersja polska Alberta Winklera [Kłoskowska 1996: 147-162].

Ilu było takich, którzy na pograniczach żyli z zachwianą, choćby częściowo tylko świadomością narodową? Później nastąpi walka o postacie historyczne, o które to dusze będą walczyć już nie narody, a państwa z całą machiną biurokratyczną. Czy Mickiewicz i Giedroyć są Litwinami, czy Kościuszko i Moniuszko są Białorusinami.

Powstanie styczniowe 1863-1864 jest pierwszym zrywem mas narodowych Rzeczypospolitej Obojga Narodów, z której z biegiem lat wyłoni się Polska katolicka, Litwa, również katolicka, ale języka litewskiego-bałtyckiego, Białoruś prawosławna (ale i katolicka) oraz Ukraina, częściowo unicka. Narody te będą walczyć przeciwko sobie prawie półtora wieku o najkorzystniejsze dla siebie granice terytorialne, w praktyce nie do uzgodnienia kryteriami etnicznymi, gdyż przebiegające szerokimi pasami liczącymi niejednokrotnie ponad setkę kilometrów. W końcu doczekają się stabilnych granic po II wojnie światowej, o których zadecydują nie one, a tak zwane zwycięskie mocarstwa. 
Był jednak na terenie Rzeczypospolitej jeszcze jeden naród, w którym zachodzą podobne jak między Polakami, Litwinami, Ukraińcami czy Białorusinami dyskusje, kontrowersje, polemiki, co do narodowego odrodzenia, czy kształtowania narodowego. To Żydzi i również wielu z nich jest przywłaszczonych niejednokrotnie bezpodstawnie Polsce, jakkolwiek ostatnio bardzo wiele się zmieniło, bo na przykład Wikipedia jest w tym przypadku niemal wiarygodna. Tak jest w przypadku Adolfa Becka (1863-1942), wynalazcy EEG; Kazimierza Funka (1884-1954), współodkrywcy witamin; Ludwika Hirszfelda (1884-1954) twórcy seroantropologii; Hilarego Koprowskiego (1916-2013), odkrywcy szczepionki przeciwko polio i - mam nadzieję - wobec wszystkich innych wynalazców.

\section{Kwestia żydowska}

W XIX wieku w Europie powszechnie rozprawiano o trzech kwestiach dotyczących zniewolonych, rozdrobnionych czy podzielonych narodów ${ }^{1}$. Były to kwestie włoska, niemiecka i polska, i to one przyczyniły się do upowszechnienia pojęcia „kwestia”, w sensie, w jakim później będzie ten wyraz używany do określeń kwestia irlandzka, węgierska czy bałkańska. W pierwszym znaczeniu, jeszcze z okresu Wiosny Ludów (1848-1849), „kwestia” dotyczyła spraw narodowych, scalenia narodowego czy niepodległości.

Kwestia żydowska pojawiła się stosunkowo późno i w zupełnie innym kontekście, gdyż Żydzi żyjący we wszystkich państwach europejskich nie byli w tym okresie jakimkolwiek europejskim narodowym problemem. Liczba Żydów w Europie na początku XIX wieku nie przekraczała 2,5 miliona osób, przy czym w państwach Zachodniej Europy nie stanowiła więcej niż zaledwie procent ludności, jakkolwiek w Europie Środkowo-Wschodniej można już było mówić o wyrazistych skupiskach ludności żydowskiej, głównie w licznych miasteczkach w Galicji. Z czasem pojęcie „kwestia” obejmowało coraz więcej wątków obcych pierwotnemu pojęciu, ponieważ nie chodziło w nim ani o scalenie narodowe żyjących w diasporze Żydów, ani o wybicie się Żydów na niepodległość, która niemożliwa była bez posiadania terytorium, a o terytorium dla Żydów w Europie nigdy nie było jakiej-

Ta część mojego eseju jest zmodyfikowaną i poszerzoną wersją na potrzeby tego artykułu fragmentu mojej książki Ludwik Zamenhof. Życie i dzieło. Recepcja i reminiscencje. Wybór pism i listów, Zakład Wydawniczy «NOMOS», Kraków 2012, s. 47-48. 
kolwiek mowy poza Żydami, tym bardziej, że Żydzi nie posiadali (podobnie jak Cyganie) żadnego europejskiego „matecznika”. Większość Żydów, jeśli upatrywała jakiegoś „odrodzenia narodowego”, to bardzo mgliście i raczej w związku z Erec Izrael, co dobitnie wyrażą w swych programach syjoniści. Również sami Żydzi stanowili wówczas najróżniejszy konglomerat różnorodnych prądów społecznych, politycznych, religijnych i, jakbyśmy dziś powiedzieli, reprezentowali najróżniejsze style życia. Główne programy narodowe Żydów koncentrowały się wokół syjonizmu i jidyszyzmu (czy fołkizmu) oraz programów asymilacyjnych, pomniejsze wokół terrytorializmu czy chasydyzmu i marginalnych programów religijno-narodowych.

Z punktu widzenia potrzeb naszych rozważań powiedzmy, że jidyszyzm upatrywał opierając się na języku żydowskim (czyli język mas żydowskich) wykuwanie się całkiem nowego narodu żydowskiego, laickiego, i ów jidyszyzm ideowo był socjalistyczny, a politycznie antybolszewicki.

Syjonizm to program powrotu do utraconej przed dwudziestoma wiekami ojczyzny o wszelkich odcieniach politycznych, od prawicowych religijnych, po rewolucyjne bolszewickie.

Terrytorializm poszukiwał nowego kraju dla Żydów, najczęściej w Ameryce Północnej czy Południowej (głównie Argentyna, program zwany Andinia), również mówiło się o Madagaskarze i Ugandzie, by tam zbudować państwo żydowskie, ze względu na niewiarę w odzyskanie Palestyny, w ówczesnych warunkach części, ale wyjątkowo ważnej strategicznie Imperium Ossmańskiego.

Programy asymilacyjne brały swe korzenie $z$ haskali i pism jej koryfeusza Mojżesza Mendelssohna (1729-1786) i programowo opowiadały się za przyjmowaniem obywatelstwa, najczęściej kultury i języka narodu zamieszkania $\mathrm{z}$ zachowaniem judaistycznej religii, znane $\mathrm{z}$ haseł: Polak wyznania mojżeszowego czy francuski Izraelita, jeszcze inni dążyli do całkowitej asymilacji. Sam judaizm stał w cieniu tych programów, choć stanowił ich religijne spoiwo.

\section{Wielokulturowość Zamenhofa. Zarys deskryptywny szczególny}

Zamenhof jako jeden z nielicznych (a może nawet i pierwszy) dostrzegł niemożliwość sprawiedliwego dokonania podziałów etnicznych i wyznaniowych $\mathrm{w}$ ramach narodów Imperium Rosyjskiego (w tym Królestwa Polskiego) i starał się przedstawić taki system społeczny, w którym procesy narodowe będą przebiegać w sposób najmniej wynaturzony, nikomu nie dając praw do sprawowania rządów w imieniu narodu. W tej epoce - rzecz 
jasna - był to postulat nie do zrealizowania, co nie znaczy, że był to postulat bałamutny.

„Ale najlepiej byłoby, gdybyśmy zamiast wielkich i mniejszych europejskich krajów, mogli mieć proporcjonalnie i geograficznie zorganizowane «Stany Zjednoczone Europy». Ale dziś - wydaje się - jest jeszcze za wcześnie, by o tym mówić, ale przynajmniej można byłoby przez oficjalną i wzajemną zgodę usunąć to wielkie zło, źródło niekończących się ciągle konfliktów, jakim jest utożsamienie nazwy kraju z grupą etniczną" [LZ: 263].

Zamenhof odrzucił wszystkie z programów żydowskich swej epoki i stworzył własny, nazwany hilelizmem (skierowany do Żydów, który później porzucił), by po modyfikacjach nazwać go humanitaryzmem. Właśnie ta propozycja posiada bardzo mocne akcenty wielokulturowości avant la lettre.

W każdym z programów rozwiązania kwestii żydowskiej Zamenhof widzi więcej wad niż zalet. Oto na przykład, jego zdaniem, terrytorialiści nie zwołają w jedno miejsce kilku milionów Żydów, by stworzyć własne państwo, owe państwo ewentualnie może stworzyć tylko część Żydów, kim więc będą pozostali, jaki ich spotka los? A dodatkowo ci, którzy pozostaną na miejscu, będą przecież jeszcze wyganiani ze swych domostw, pod pretekstem, że mają własne państwo!

Z podobnych powodów odrzuca on jidyszyzm (fołkizm). Przecież nie zostanie ów program uznany przez większość pozostałych Żydów, poza tym, co ma znaczyć programowa autonomia fołksistów, jaka? A jidysz? Jidysz stanie się językiem strefy bałtycko-czarnomorskiej, jak nazywa Zamenhof strefę osiedlenia. A więc jakim językiem będą posługiwać się inni Żydzi, w jaki sposób będą się między sobą porozumiewać?

„Co prawda my, Żydzi wschodnioeuropejscy, mamy wspólny język, którego używali nasi rodzice i dziadowie, którym posługiwaliśmy się w dzieciństwie i którym jeszcze dziś często się posługujemy, to żargon. (...) Ale taki naród, doskonalący germański jidysz w zonie rosyjsko-polskiej między Bałtykiem a Morzem Czarnym nigdy nieuznany by został przez żadne hebrajskie stronnictwo, mało tego, jego szanse istnienia byłyby efemeryczne, bez żadnych widoków na przyszłość" [LZ: 51].

Rozprawia się on też z bezsensownością tak szczególnie uwielbianego przez francuską inteligencję procesu asymilowania językiem i kulturą wszystkich tych, których Republika przerabia na Francuzów. Agnieszka Jagodzińska [2010: 15-31] dostrzegła ten najważniejszy dla całej twórczości Zamenhofa paradygmat, polegający na tym, że asymilacja nie daje odpowiedzi na zagadnienia dotyczące akulturacji (są to pojęcia niekom- 
patybilne), ponieważ nie da się nigdy zasymilować żadnej grupy etnicznej do innej, zawsze wyjdzie $\mathrm{z}$ tego jakiś twór hybrydowy, co uwidoczniły już badania uczniów Roberta Ezra Parka w Szkole Chicagowskiej na początku XX wieku.

Zamenhof miał tę świadomość, gdy pisze w związku z asymilacją, że tworzy ona: „«krawców szewskiego zawodu», a o tych którzy poddają się asymilacji powie: "Jesteście niczym nietoperze rozerwani między dwoma obozami, ptaków i czteronogów, i nie wiecie do kogo się przyłączyć»" [LZ: 189].

Zagadnienie asymilacji uważał więc Zamenhof za największą tragedię, jaka rozgrywa się wśród mniejszości narodowych. Po prostu asymilacja jest wykorzenieniem o negatywnych skutkach psychospołecznych dla każdej jednostki i w każdych okolicznościach. I zawsze odbywa się ona pod dyktat i przymus większości. I w końcu dokonuje on druzgocącej krytyki syjonizmu, wówczas gdy większość inteligencji żydowskiej również walczyła $\mathrm{z}$ ideami syjonizmu, a masy żydowskie ślepo lgnęły do niego.

Wiedział on oczywiście, że judaizm i pamięć po przodkach zespala Żydów, ale zdawał sobie sprawę z tego, że wyłącznie na bazie religii i tradycji nie można będzie zbudować nowoczesnego państwa żydowskiego, gdyż - spoglądając politycznie w daleką przyszłość - napisze w 1905: „Ale nawet gdyby wierzyć w cuda i założyć, że wszyscy Żydzi znajdą się w Palestynie, to analogicznie do trzech pozostałych wypędzeń, i tym bardziej dziś, gdy Palestyna jest rozpostarta na „wulkanie”, doczekamy się po kilkudziesięciu, a może po setce lat... nowego, czwartego wygnania!” [LZ: 36].

Przedstawiał on również racje ideologiczne. Uznał on budowę państwa syjonistycznego nie tyle za utopię, ile za niepożądany proces, a dążenia państw narodowych do niepodległości za uprawnione, ale nie najważniejsze sprawy epoki, gdyż zdaniem Zamenhofa państwo narodowe jest w swej istocie dalekie od dewizy „wolności, równości i braterstwa”, w istocie jest ono instrumentem narodu dominującego do dławienia czy asymilacji mniejszości, nie traktując ich na równej stopie z narodem dominującym, co jest zamachem na wolność mniejszości narodowych i jednostek, i co $\mathrm{z}$ gruntu jest niesprawiedliwe.

Poza tym Zamenhof nie wierzył w to, że masy żydowskie, pod wpływem zabobonnych cadyków poddadzą się jakiejkolwiek reformie religijnej czy społecznej. To na inteligencji spoczywa obowiązek oświecenia mas. Tu Zamenhof w niczym nie różni się od jakiegokolwiek środkowoeuropejskiego intelektualisty, który kocha swój zabobonny lud, z którym nie ma żadnego 
kontaktu ideowego, intelektualnego i towarzyskiego. I był on w tej krytyce nieoświeconych mas żydowskich jako intelektualista nieodosobniony. $\mathrm{Na}$ marginesie warto zaglądnąć do krytyki „żydowskości” u Karola Marksa [1962: 420-458] czy Juliana Tuwima [Matywiecki 2007: 254-330].

Niestety, syjonizm, przeciwnie, wzmacnia u Żydów tę idée fixe, tę ich dolę. Dlatego działalność syjonistów sama przez się musi być nazwana bezużyteczną. Sam syjonizm, gdy znajdzie się w rękach intelektualistów, wcześniej czy później zostanie przez nich unieważniony, by uratować hebrajskość [LZ: 246].

\section{Dylematy narodowe judaizmu rabinicznego, dylematy Zamenhofa}

Zamenhof jako wierzący Żyd (matka głęboko wierząca, ojciec ateista) musiał zadać sobie pytanie, w jaki sposób judaizm rozwiązuje kwestie narodowe, a dodatkowo jako zwolennik haskali musiał odpowiedzieć sobie na pytanie, gdzie jest miejsce wszystkich innych narodów, które nie dostąpiły wybraństwa.

Sam judaizm rabiniczny przeżywa pod koniec XIX wieku największą niespójność, ponieważ wchodzi on w nowoczesność, do której nie jest przygotowany, a w Talmudzie (tylko babiloński liczy 2,5 miliona słów, a jeszcze jest palestyński oraz tradycja ustna) nie ma żadnych uwarunkowań dziejowych, żadnych interesów klasowych, koterii, problemów rasowych, etnicznych, językowych, materialnych czy narodowych, jest tylko komentarz do prawdy ostatecznej, do Tory. I ten judaizm spotyka się z erą nowoczesną, z oświeceniem, gdzie po raz pierwszy wszystkie europejskie religie mierzą się z laickością, ateizmem i socjalizmem, ale również w nieznanych dotychczas rozmiarach $\mathrm{z}$ kwestią narodową. Judaizm rabiniczny staje przed teoretycznym problemem, czy wybraństwo Izraela, „wywyższa” naród żydowski nad inne narody i w jakim sensie. Ortodoksyjni rabini twierdzą, że tak, ale coraz częściej argumentacja sprowadza się do teologicznego (jeśli można mówić o jakiejkolwiek teologii w związku z judaizmem) dyskursu, który, reasumując, brzmi zarówno TAK, jak i NIE.

W filozofii żydowskiej występuje pięć par mędrców, do których wraca każde pokolenie Żydów. Ostatnią parą są Hillel i Szammaj, z czasów Heroda Wielkiego (73-4 p.n.e.). Z czasem ich spory stały się tak słynne i anegdotyczne, że przekroczyły świat judaizmu. Pilny student Talmudu, w którym Hillel i Szammaj pojawiają się wielokrotnie i niemal nierozłącznie, musi umieć przedstawić z jednej strony racje Hillela, z drugiej strony Szammaja. 
Ani żydowskie „średniowiecze”, ani „renesans”, aż do oświecenia niewiele zmienił z owej myśli spekulatywnej, a nawet dodał nową metodę pilpul, polegającą na dialektycznym zestawianiu argumentów za i przeciw danej wykładni prawa w celu znalezienia ostatecznego rozwiązania. Swoje źródła ma w komentarzach rabinów Rasziego (1040-1105) z Troys w Szampanii i Majmonidesa (1135-1204) z Kordowy w Andaluzji i do dziś jest praktykowany w niektórych ortodoksyjnych uczelniach rabinicznych.

Między europejskim średniowieczem a oświeceniem pojawiają się nowe prądy judaizmu, w tym kabała, w końcu chasydyzm. Między kabałą a chasydyzmem mamy do czynienia w Europie Środkowo-Wschodniej $\mathrm{z}$ największą $\mathrm{w}$ dziejach schizmą judaizmu, mianowicie $\mathrm{z}$ sabbatyzmem, następnie frankizmem.

Owe rozważania „z jednej strony, ale z drugiej strony” odnajdziemy we wszelkich spekulacjach intelektualnych Żydów, między innymi w klasycznym dziele literatury jidysz Dzieje Tewji Mleczarza Szolema Alejchema (1859-1916), znanym też z musicali i filmu Skrzypek na dachu. „Znaczy to, że w judaizmie sama sprzeczność jest integralną częścią objawienia” [Mello 2002: 43].

Noachizm jest jednym $z$ nielicznych dylematów judaizmu dotyczącym stosunku judaizmu do Nie-Żydów i utrzymał się w judaizmie od „pierwszych dni" w tradycji ustnej i znalazł swoje miejsce w rozważaniach w Talmudzie babilońskim. Pan nakazuje Noemu ocalić przed potopem ludzkość i wszelkie stworzenie $w$ arce. Noe uznany jest wprawdzie w judaizmie za patriarchę, ale wyłącznie w sensie pierwszych pokoleń protoplastów po Adamie i Ewie. Są owi patriarchowie wprawdzie złączeni przymierzem z Abrahamem, ale nie są wzorem religijnym dla późniejszego judaizmu, nie są związani z Ziemią Obiecaną i nie mają żadnej mocy profetycznej, nie są jeszcze Żydami.

W Talmudzie babilońskim znajdujemy taki komentarz: „Każdy z Potomków Noacha, który poświęca się studiowaniu Siedmiu Uniwersalnych Praw, jest zdolny osiągnąć poziom duchowy wyższy od tego, jaki posiada Najwyższy Kapłan Żydów" [Baba Kamma 38a]. Oto siedem Praw uniwersalnych, które łączą ludzkość na równi z wyznawcami judaizmu (w skrócie):

1) sprawiedliwość, obowiązek ustanawiania sędziów i trybunałów;

2) zakaz idolatrii;

3) zakaz bluźnierstwa;

4) zakaz niedozwolonych stosunków seksualnych;

5) zakaz zabijania; 
6) zakaz kradzieży;

7) zakaz spożywania części żywego zwierzęcia.

„Stanowią one kodeks zachowań, jakie według judaizmu są konieczne dla współżycia ludzkiego. Po części mieszczą się one jako również w ramach «rzeczy niezbędnych», jakie pierwszy sobór w Jerozolimie narzucił chrześcijanom pochodzenia pogańskiego (Dz. 15: 20, 29)", [Mello 2002: 157].

Według judaizmu wszyscy Nie-Żydzi żyjący w zgodzie z tymi siedmioma zasadami należą do Sprawiedliwych (wśród narodów świata) i mają zapewnione swe miejsce w przyszłym, sprawiedliwym świecie. Są nazywani B’nei Noah (Dziećmi Noego) i jeśli chcą, mogą uczęszczać do synagogi.

Tradycja precyzuje, że zasady noechizmu znajdują się pośród 613 przykazań religii mojżeszowej (micwot), w tym, w samym Dekalogu. Z punktu widzenia ortodoksyjnej tradycji rabinicznej chrześcijanie "Świętej Trójcy” czyli katolicy, prawosławni i protestanci nie są włączeni w przyszły wspaniały świat, gdyż są bałwochwalcami (politeistami), w przeciwieństwie do nielicznych chrześcijan monoteistów (Chrystadelfianie lub Bracia w Chrystusie oraz Socynianie).

Z czasem, a głównie w związku z Zagładą ortodoksyjna tradycja rabiniczna musi ustąpić nawet w Izraelu wobec Sprawiedliwych wśród narodów świata, których uznano za ratujących Żydów z czysto humanitarnych motywów podczas Holocaustu z narażeniem własnego życia. To właśnie tych „bałwochwalców”, paradoksalnie, jest najwięcej pośród Sprawiedliwych wśród narodów świata, którzy ratując jedno życie ratowali cały świat.

Raz jeszcze wyrażę moją wątpliwość co do tego, czy Zamenhof znał naochizm, czy też nie chciał nim komplikować swojego hillelizmu, ale doszedł on jako „wierzący” Żyd narodu wybranego, do „bezwzględnej równości” wszelkich ludzi i narodów świata, tłumacząc wybraństwo nie jako wywyższenie, ale jako dodatkowy obowiązek dawania świadectwa czy świecenia przykładem, który Pan nakazał Żydom wobec Nie-Żydów. Zamenhof dokonał wyjątkowo mocnej krytyki judaizmu, zerwał ze związkiem narodu żydowskiego z religią żydowską i jakby (poniżej cytowaną konstatacją) sam wypisał się z tradycyjnego judaizmu: „Żydzi posiedli tę nieszczęśliwą myśl, by przekazać światu etyczno-filozoficzny światopogląd i w tym samym czasie nierozłącznie związać go z jednym narodem! I gorzko za to płacą! Religia żydowska, która w swej istocie miała za cel szeroką falą rozlać się po świecie, od początku zakuła się w kajdany, zjawiła się przed światem nie jako monoteizm, ale jako judaizm. I w ten sposób od swych urodzin, judaizm przeniósł w Boży świat wyrok wiecznej tułaczki swoim adeptom. 
Nie był w stanie wszystkiego wchłonąć, a nawet wzajemnie komunikować się z zewnętrznymi elementami, w ten sposób czyniąc je wiecznie obcymi. Nie mógł judaizm wtopić się w inne narody, bo uznaje on tylko jednego Boga dla każdego narodu, a Bóg ten nie może być zastąpiony innym. Wchłonąć innych religii też nie mógł, bo jego religia nie jest przeznaczona dla wszystkich, którzy poszukują prawdy, lecz tylko dla tych, którzy godzą się wypełniać prawo, więc tylko dla synów Izraela" [LZ: 223-224].

Proponuje hilelizm, jako zreformowany judaizm, który ma uniwersalny - zdaniem Zamenhofa - charakter. Każdemu jest bliski i każdemu służy, budując międzyludzki pokój: „1. Odczuwamy i uznajemy istnienie najwyższej Siły, która rządzi światem i Siłę tę nazywamy Bogiem. 2. Bóg włożył swoje prawa w serce każdego człowieka, w formie świadomości, dlatego bądź zawsze posłuszny głosowi rozsądku, gdyż jest to niezamilkły głos Boga. 3. Istota wszystkich praw Boskich jest wyrażona w następującej zasadzie: kochaj bliźniego i postępuj wobec niego tak, jakbyś chciał, by on postępował w stosunku do ciebie. Niczego nie rób jawnie, ani skrycie, o czym twój wewnętrzny głos mówiłby, że to się nie spodoba Bogu. Wszystko inne, co usłyszysz od swoich nauczycieli czy przodowników, a co nie zawiera się w pierwszych trzech punktach, to wyłącznie ludzkie komentarze, które mogą być prawdziwe, ale mogą też być błędne" [LZ: 229]. I dalej: „Do tej religii może przystąpić każdy, który odrzuca nawet wszelką religię, ponieważ żaden przyzwoity człowiek nie może negować 2 . i 3. zasady hilelizmu. Nawet najbardziej konsekwentny ateista nie może przeciwstawić się 1. zasadzie, dotyczącej istnienia niepojętej Siły, bowiem to, co on nazywa naturą, my nazywamy Bogiem, pozostawiając każdemu jego własny sposób interpretacji. Niewierzący hilelista może pod pojęciem Boga rozumieć siły przyrody czy ogólnoludzką moralność; przesądny hilelista może widzieć Boga siedzącego na tronie w niebie i stamtąd oglądającego raj i piekło; obydwoje będą prawymi hilelistami i jeden nie będzie mógł drugiemu zarzucić bezbożności, gdyż jeśli tylko wypełniają oni zasady, nikt z nich nie grzeszy przeciwko hilelizmowi” [LZ: 232].

Reforma judaizmu przez Zamenhofa sprowadza się do redukcji całego Prawa zamkniętego w sensie ontologicznym do kreacjonizmu (Bóg jest $\mathrm{w}$ wersji religijnej, natura jest $\mathrm{w}$ wersji ateistycznej). Jest to u Zamenhofa na swój sposób zinterpretowana myśl Barucha Spiznozy (1632-1677) z jego słynnej propozycji nr 14: „Nie istnieje żadna substancja, która by nie była Bogiem" - a zatem, substancja tworząca cały istniejący wszechświat i Bóg są całkowicie tożsame. W sensie moralnym Zamenhof nawiązuje do złotej 
zasady Hillela (nie czyń drugiemu co Tobie niemiłe), etycznie do samorealizacji w pełnym przymierzu z Bogiem (nie oszukuj siebie i Pana) i pasuje zarówno do członków narodu wybranego, jak i członków wszystkich innych narodów.

Gdy Zamenhof opublikował hillelizm, Żydzi europejscy nie chcieli słyszeć o żadnych reformach, a nurty reformatorskie judaizmu zaczęły rodzić się głównie w Stanach Zjednoczonych. Czy Zamenhof odrzucił judaizm? Nie, ale nigdy nie stosował go literalnie i do końca swego żywota; był Żydem reformowanym i zwolennikiem reform. Stworzył on dla judaizmu i dla innych wyznań, dla hebrajczyków, jak i innych narodów „platformę" współżycia, którą nazwie humanitaryzmem.

\section{Reforma judaizmu jako condicio sine qua non wielokulturowości}

Przełom dokonuje się wówczas, gdy Zamenhof zauważa, że nie dociera on ze swym apelem do Żydów, stąd zwraca się, jakbyśmy to dziś powiedzieli (z pewnością wskutek międzynarodowego sukcesu esperanta po Kongresie w Boulogne-sur-Mer w1905 i Genewie w 1906), do wszystkich ludzi dobrej woli z nowym przesłaniem - humanitaryzmem. Zmienia on całkowicie swój program, ponieważ zauważa, że nie da się zreformować tylko Żydów, po to, by mogli wejść w majestacie dumy w nowoczesność, a nade wszystko uniknąć najróżniejszych pożóg nacjonalistycznych. „Zreformować” więc należy nie tylko Żydów, ale wszystkich, którzy pragną rozwiązać jakiekolwiek kwestie narodowe. W istocie bowiem naród jest konstrukcją ideologiczną, a życie jednostki nie odbywa się w narodzie, lecz wśród sąsiadów, w mieście i na wsi, w regionie. Cóż jednostka jest winna, że urodziła się tu, a nie tam, że wychowano ją w tamtej, a nie tej religii, że nauczono ją tego, a nie tamtego języka? Oto zagadnienia, które znajdują w specyficzny sposób rozwiązanie $w$ humanitaryzmie.

Formułując normatywne zasady wielokulturowości odnosi się wrażenie, że Zamenhof konstruuje zasady konduity wielokulturowej, powszechnej, uniwersalnej, buduje pomost między narodami, ponieważ jest przekonany, że bez nowej świadomości nigdy nie zaistnieje pokój między narodami europejskimi Imperium Rosyjskiego, a Żydzi nigdy masowo nie opuszczą Europy Wschodniej (terenów byłego Królestwa Polskiego oraz strefy osiedlenia) i że syjonizm nie zwycięży, jako naczelna idea narodowa wśród Żydów. I powiedzmy szczerze i od razu, syjonizm nigdy by nie zwyciężył, i nie zrealizował się w państwie Izrael, gdyby nie Endlösung der Judenfrage. 
Patrząc z innej strony Zamenhof wszedł na nierozwiązywalny na gruncie antropologii kulturowej problem, ponieważ kultura, jakkolwiek jest pojęciem uniwersalnym (symbole, etyka, wartości), to nie istnieje ona w liczbie pojedynczej, tylko realizuje się w konkretnych kulturach, w konkretnych językach (systemach). Komunikacja między nimi odbywa się za pomocą arbitralnych symboli, które należy tłumaczyć, czyli odnajdywać najbliższe wartości, wiedząc, że nigdy nie będą one tożsame. Jak więc w takich okolicznościach znaleźć modus vivendi na harmonijne, bezkonfliktowe, sprawiedliwe współistnienie najróżniejszych grup etnicznych o różnej aksjologii, różnych języków? Właśnie na ten dylemat odpowiedzią miało być esperanto.

\section{Wielokulturowość Zamenhofa. Zarys normatywny szczególny}

Pierwszy raz Humanitaryzm pojawia się drukiem w 1906, następnie w 1913 roku. Ostatnia wersja Humanitaryzmu pochodzi z roku 1917, roku śmierci Zamenhofa i jest zredagowana w 10 zasadach (tak jak 10 jest przykazań danych Mojżeszowi). O ile wcześniej Zamenhof nazywał je dogmatami, teraz nazywa je zasadami. W ostatniej wersji nie pojawia się w Humanitaryzmie expressis verbis język esperanto, jakkolwiek pojawia się język neutralny. Do ostatniej wersji Humanitaryzmu dołączona jest część zaczerpnięta z Projektu fundamentalnych zasad neutralnej religii z 1914 roku.

Przede wszystkim w deklaracji humanitaryzmu znikają takie pojęcia, lub są wymienione z niuansem pejoratywnym, jak naród, państwo, mniejszość narodowa, a takim jak patriotyzm Zamenhof nadaje nowe znaczenie.

Oto kilka najważniejszych pryncypiów Humanitaryzmu z 1905 roku, całość znajdzie Czytelnik w mojej książce o Zamenhofie. Dziś niektóre z tych zasad wydają się jakby oczywiste, ale w czasie ich tworzenia przez Zamenhofa, były istną herezją, bo niemal wszystkie narody Europy walczyły o to, co Zamenhof zanegował. Oto kilka przykładów:

\section{Nie narody są „właścicielami” krajów (państw):}

„Uważam, że każdy kraj nie należy do tej czy innej grupy etnicznej, lecz w równym stopniu do wszystkich jego urodzonych w nim, lub naturalizowanych mieszkańców, bez względu na to, jakie można przypisać im pochodzenie, język, religię lub społeczną rolę. Dlatego identyfikacja interesów kraju 
z interesami takiej czy innej grupy etnicznej czy religijnej, pod pretekstem historycznych praw, które pozwalają jakiemuś narodowi sprawować rządy nad grupami etnicznymi i pozbawiać je elementarnego prawa do ojczyzny, uważam za pozostałość barbarzyńskich czasów, kiedy istniało prawo pięści i miecza" [LZ: 268].

Nazwy geograficzne winny mieć charakter geograficzny lub inny, ale nigdy nie etniczny. Na przykład Kanada, Islandia, Quebek, Brazylia:

„Uważam, że każde państwo i wszystkie prowincje powinny posiadać nazwy geograficznie neutralne, nie zaś nazwy wywiedzione $\mathrm{z}$ ich narodów, języków czy wyznań, bowiem właśnie takie nazwy własne wielu krajów są głównym powodem, dla których jedni mieszkańcy uważają się za Panów innych. I ci Panowie uważają, że inni, którzy są tak samo jak ci Panowie naturalnymi synami tej samej ziemi, są związani z interesami innego kraju, podczas gdy ten kraj jest im obcy" [LZ: 268].

Człowiek ma prawo do własnego języka, wyznania, ale ma stosować to prawo nie będąc w konflikcie $\mathrm{z}$ innymi:

„Uważam, że w swym prywatnym życiu każdy Człowiek ma pełne i bezdyskusyjne prawo posługiwać się tym językiem lub dialektem, który jest mu najbliższy i wyznawać tę religię, która go najbardziej zadowala, jednak komunikując się z innymi ludźmi powinien, na ile to jest tylko możliwe, nie narzucać swoich etnicznych i religijnych przekonań, posługując się neutralnym językiem, neutralną etyką, neutralnymi obyczajami, neutralnym kalendarzem itp. Dopóki na świecie problem neutralności jako takiej nie zostanie definitywnie rozwiązany, będę musiał, przynajmniej w stosunkach z moimi współideowcami, używać takiej konduity, jaką oni zaaprobują. Mam świadomość, że tam, gdzie nie ma walk etnicznych, to dla współobywateli kraju czy miasta rolę języka neutralnego może odgrywać język urzędowy lub ukształtowany literacko język, którym posługuje się zdecydowana większość mieszkańców. Ma to być jednak jedynie chwilowe praktyczne rozwiązanie dla mniejszości, która ceduje swe prawa na rzecz większości, nie zaś upokarzający atrybut, jako dług wdzięczności wobec większości” [LZ: 268]. 
Człowiek posiada tylko małe ojczyzny, duże ojczyzny nie sa bytami, tylko ideami:

„Moją ojczyzną mogę nazwać tylko ten kraj, w którym się urodziłem, i który jest miejscem mojego stałego zamieszkania. Jeśli z jakichś powodów kraj moich narodzin nie jest krajem mojego stałego zamieszkania, mogę ten kraj nazywać „fizyczną ojczyzną”, „krajem narodzin”, „polityczną ojczyzną” bądź „krajem zamieszkania”. Nie mam prawa nazywać moją ojczyzną tego kraju, w którym mieszkali moi przodkowie, albo w którym mieszka większość moich pobratymców, bez względu na to, jak piękny byłby ten kraj dla mnie, ponieważ nazwanie go ojczyzną byłoby grzechem przeciwko zasadzie, która mówi, że każdy kraj należy do jego naturalnych mieszkańców, i byłoby to w sprzeczności z moimi obywatelskimi powinnościami. Jednak ze względów politycznych, historycznych, etnograficznych i geograficznych idea kraju i jego granic jest zbyt nieprecyzyjna i niepewna, i często prowokuje spory i waśnie, dlatego definiując kraj, który nazywam ojczyzną, muszę powodować się nie moimi sympatiami czy etnicznym gustem, lecz bezstronnym stanowiskiem ważnym we wszystkich okolicznościach i miejscach, które zostaną uznane przez wszystkich moich współideowców" [LZ: 269].

Patriotyzm dotyczy wyłącznie małej ojczyzny i ludzi, których znam:

„Patriotyzmem nazywam służbę dla wszystkich moich krajanów, a szczególnie dla wszystkich moich sąsiadów, bez względu na ich pochodzenie, język, wyznanie czy pełnioną przez nich rolę społeczną. Nigdy nie nazwę patriotyzmem służby dla określonej grupy etnicznej, albo wrogość do innej. Uważam, że żarliwa miłość do swojego miejsca urodzin i do swojego ogniska domowego jest sprawą najoczywistszą i wspólną wszystkim ludziom, co może być zdewastowane wyłącznie przez zewnętrze, nadzwyczajne okoliczności” [LZ: 269].

\section{Konkluzje, opinie, wnioski końcowe}

Po raz pierwszy zjawisku wielokulturowości nadaje nazwę autor recenzji pod tytułem Lance, A Novel about Multicultural Men zamieszczonej 27 czerwca 1941 w „New York Herold Tribune” w jednej z powieści Edwarda Haskella. Przedstawia on w niej nowe społeczeństwo amerykańskie, kosmopolityczne, wielorasowe, wielojęzyczne, w końcu wielokulturowe, dla 
którego patriotyzm i inne wartości wiążące obywatela z państwem straciły jakikolwiek sens [Lacorne 1997: 20].

Współcześnie Wikipedia definiuje wielokulturowość - zarówno deskryptywnie, jak i normatywnie - jako ideę i model społeczny, według której społeczeństwo powinno cechować się występowaniem grup o różnym pochodzeniu i wyznających sprzeczne systemy normatywne (określające metody kontroli społecznej sposoby oceniania i kontroli postępowania jednostki i osób ją otaczających) [https://pl.wikipedia.org/wiki/Wielokulturowość [11.07.2015].

Zdaniem Zamenhofa wielokulturowość, na którą składają się najróżniejsze grupy etniczne zamieszkujące to samo terytorium to fenomen społeczny, w takim samym sensie jak klasowość, $\mathrm{z}$ tym że etniczność posiada charakter segmentowy w społeczeństwie. O ile klasowość dotyczy antagonizmów społecznych w sensie posiadania, o tyle etniczność jest najważniejszym elementem segmentowości, gdzie ani kryteria klasowe, ani polityczne nie wywołują cech dystynktywnych; etniczność jest bowiem danym z natury sposobem więzi społecznej, utrwalanym kulturowo, na który klasowość nie ma wpływu. Ani podziały klasowe, ani podziały polityczne nie są w stanie zniszczyć etniczności, która rządzi się własnymi prawami. W tym sensie nie może być mowy o podziale społeczeństw na narody i grupy etniczne, gdyż naród i etnos z punktu widzenia jego członków jest jednym i tym samym. Różnica polega na tym, że naród to ten etnos, który uzyskał instrument władzy nad innymi etnosami w postaci państwa.

Humanitaryzm - jak pisze Zamenhof - jest „nauką, która nie odrywając człowieka od jego naturalnej ojczyzny, języka, ani religii, daje mu możliwość uniknięcia wszelkiego fałszu i sprzeczności w jego zasadach narodowo-religijnych oraz możliwość porozumienia się z ludźmi wszystkich języków i religii na fundamencie neutralnoludzkim, na zasadach wzajemnego braterstwa, równości i sprawiedliwości” [LZ: 13].

Dlatego uważam, że Zamenhof jako pierwszy odkrywa zjawisko wielokulturowości, opisuje je i dąży do nadania mu charakteru normatywnego, by nie była owa wielokulturowość procesem barbarzyńskim, ale ucywilizowanym, w którym życie nawet jeśli nie jest sielanką, to jest znośne. Jakże aktualny jest ten problem dziś, gdy Europa staje się celem kolejnej wędrówki ludów. 


\section{Bibliografia}

Przy notach bibliograficznych w tekście w zapisie oksfordzkim, czyli w [nawiasach] za cytacją pojawia się taki oto zapis [LZ: nr str.]. Znaczy to, że jest to cytat pochodzący z mojej książki Ludwik Zamenhof. Życie i dzieło. Recepcja i reminiscencje. Wybór pism i listów. Zakład Wydawniczy «NOMOS», Kraków 2012. Książka składa się z tekstu głównego oraz aneksu, w którym pomieściłem najróżniejsze prace i listy Zamenhofa. Wyodrębnianie ich [nawiasami] ze specjalnym zapisem powodowałoby bałagan, a tak wszystko znajduje się w jednej pracy, do której ten zapis $\rightarrow$ [LZ: nr str.] odsyła.

Alejchem Sz. (2005), Dzieje Tewji Mleczarza, przeł. Anna Dresnerowa, Wrocław.

Bałaban M. (1983), Historja i literatura żydowska, t. I + II + III, Lwów - Warszawa - Kraków, Wydawnictwo Zakładu Narodowego imienia Ossolińskich, (bez daty wydania), reprint Wydawnictwa Artystyczne i Filmowe, Warszawa.

Breton R. (1995), L'ethnopolitique, Paris.

Clément M. (2011), L’homaranisme. De la sagesse d'Hillel aux lumières juives, (IVe édition, revue et corrigée), http://www.adhuc.eu/homaranisme.pdf, [19.03.2011].

Graetz H. (1929), Historja Żydów, t. I-IX, przeł. St. Szenhak, Wydawnictwo „Judaica”, Warszawa, reprint Krajowa Agencja Wydawnicza, Kraków 1990.

Hadas-Lebel M. (2005), Hillel, un sage au temps de Jésus, Paros.

Jagodzińska A. (2008), Pomiędzy. Akulturacja Żydów Warszawy w drugiej połowie XIX wieku, Wrocław.

Jagodzińska A. (2010), Asymilacja, czyli bezradność historyka. O krytyce terminu i pojęcia, [w:] K. Zieliński (red.), Wokót akulturacji i asymilacji Żydów na ziemiach polskich, Lublin.

Jagodzińska A. (2012), Od Hilelizmu do Homaranizmu. O religijnym i narodowym uniwersalizmie Zamenhofa, [w:] Ludwik Zamenhof wobec „kwestii żydowskiej”. Wybór źródeł, oprac. A. Jagodzińska, Kraków.

Janion M. (2000), Do Europy tak, ale razem z naszymi umarłymi, Warszawa.

Kłoskowska A. (1996), Kultury narodowe u korzeni, Warszawa.

Kuncewicz P. (2000), Goj patrzy na Żyda. Dzieje braterstwa i nienawiści od Abrahama po współczesność, Warszawa.

Lacorne D. (1997), La crise de l'identité américaine. "Du melting pot « au multiculuralisme«, Paris.

Marks K., Engels F. (1962), W kwestii żydowskiej. Dzieła Wszystkie, t. 1, Warszawa.

Matywiecki P. (2007), Twarz Tuwima, Warszawa.

Mello A. (2002), Judaizm, przeł. K. Stopa, Kraków.

Sacha P. (red.), Talmud Babiloński, (2010), Kraków.

Sand S. (2008), Comment le peuple juif fut inventé, Paris.

Silfer G. (1986), Se mi ne estus Hebreo... Una ricerca sulle origini dell'esperanto, Milano. 
Tollet D. (1999), Historia Zydów w Polsce od XVI wieku do rozbiorów, Warszawa.

Tyloch W. (1987), Judaizm, Warszawa.

Zamenhof L. (1901), Гиллелизмъ. Проектъ рғшенія еврейскаго вопроса, Reprint oryginału rosyjskiego wraz z tłumaczeniem na esperanto przez Adolfa Holzhausa, Helsinki: Fondumo Esperanto, 1972.

Żelazny W. (2002), Mythes et réalité du savoir linguistique des Européens, „Europe en formation", nr 2, s. 77-94.

Żelazny W. (2004), Język uniwersalny w świecie religii i spirytyzmu, „Przegląd Religioznawczy", nr 3-4, s. 95-119.

Żelazny W. (2010), Czy możliwa jest sprawiedliwość językowa, „Kultura i Społeczeństwo”, nr 2, s. 157-169.

Żelazny W. (2012), Ludwik Zamenhof. Życie i dzieło. Recepcja i reminiscencje. Wybór pism i listów, Kraków.

\section{SUMMARY}

\section{Zamenhof multiculturalism avant la lettre with partieular emphasize of religious aspect}

Zamenhof was one of the few thinkers who noticed the impossibility of a just dispensation between ethnicities and religions in the Russian Empire. He aspired to present a social system where national actions could run in the most natural way and where no one has the right to rule on behalf of the nation. In Zamenhof's opinion multiculturalism composed of different ethnical groups inhabiting the same territory is a social phenomenon just as a class system. However, if class system relates to social antagonisms in the matter of possession, then ethnicity is the most important element of segmentation where neither ownership, class nor political criteria are distinctive as ethnicity is a natural and culturally established social bond. Zamenhof rejected all political Jewish programs of his age and created his own program called Hillelism (which was directed at Jews and which he later abandoned) which after modification was renamed as Humanitarianism. Precisely this proposition has many common characteristics with multiculturalism avant la letter.

KEYWORDS: multiculturalism, ethnicity, nation, Zionism 